\title{
Comparison of scientific literacy skills based on gender in north Labuhanbatu district
}

\author{
Yenni Sinaga $^{1}$, Melva Silitonga ${ }^{2 *}$, Ely Djulia $^{2}$ \\ ${ }^{I}$ Student of Biology Education Program, Postgraduate, Universitas Negeri Medan, Indonesia \\ ${ }^{2}$ Lecture of Biology Program, Universitas Negeri Medan, Indonesia
}

*Corresponding Author: Melva Silitonga, Lecture of Biology Program, Universitas Negeri Medan, Indonesia

\begin{abstract}
This research was conducted to describe $10^{\text {th }}$ grade student's science literacy, to find out science literacy based on regions in context dimension, and $10^{\text {th }}$ grader student's knowledge and attitudes in North Labuhanbatu Utara. The sample was 193 students, taken by using purposive sampling technique. The data was collected by using science literacy test and questionnaire. The result showed student's science literacy in North Labuhanbatu Utara was 36.36 (low). The result of student's science literacy based on its dimensions were: context dimension was 33.71, competence was 36.93, knowledge was 30.50, and attitudes was 44.27. Student's science literacy based on regions showed there was no difference in science literacy between urban regions and rural regions of North Labuhanbatu Utara, both were in low level.
\end{abstract}

Keywords: science literacy, context, competence, knowledge, attitudes, region

\section{INTRODUCTION}

One of the keys to successfully facing the challenges of the $21^{\text {st }}$ century is to be scientifically literate, or has ability to understand, communicate, and apply biological concepts in real life. Science literacy now become such requirement that people have to master, whether in daily life or in working environment.A scientifically literate personcan use the scientific information they have to overcome problems in their daily lives and produce useful scientific products.

Science literacy is a necessary element of education in modern science and technology driven society and it is crucial to teach science to all citizens, not only for those who actively involved in science and early choose careers in science (Mchearson, 2008). Walberg (1983) in Ogunkola (2013) explained that science literacy will enable individuals to participate more intelligently in the productive economy sector. Therefore, science literacy must be seen as a form of human capital that affects the economic welfare of a nation in a number of different ways.

Generally, in Indonesia, it is well known that the level of science literacy of Indonesian students as measured by PISA shows a worrisome condition. Many efforts have been done regarding this situation, such as producing curriculum reformation such as K-13 Curriculum. The quality of science literacy in Indonesia according to Programme for International Students Assessment (PISA) in 2015, placed Indonesia in rank $66^{\text {th }}$ out of 72 countries participated (OECD, 2016). The survey also shows Singapore as the first rank for science, reading and mathematics (Kemendikbud).

Anggraini (2014) shows that science literacy of $10^{\text {th }}$ grade students in Solok city was "very low", with the score obtained was only $27.94 \%$ (very low $\leq 54 \%$ ). Among many factors that cause this phenomenon are student's low achievement in subject matter that has never been studied, not accustomed in working on problems using discourse, and learning process that does not support students in developing scientific literacy skills. The low achievement in science literacy also caused by teacher does not habituate students by learning process that support science literacy (Putri, 2014). Siagian (2017) also found out the low science literacy in junior high school in North Labuhanbatu Utara, by using questionnaire, it was found out $65 \%$ respondents said the media is rarely used in learning and practicum. This is due to inadequate laboratory facilities and lack of teacher commitment 
in practicum activities.

There is a relationship between science literacy and the welfare of a nation, Laugksch (1999) argues that only countries whose citizens have an appropriate level of science literacy will be able to maintain a supply of technically trained scientists, engineers and personnel. Therefore, student's science literacy is an important part of science education to prepare students as prosperous human resources in the future.

Seeing how important science literacy is, then it is necessary to know science literacy skills of High school students in North Labuhanbatu Utara to provide accurate information how far student's achievement in science literacy. This research was held as first step to improve quality of education in North Labuhanbatu Utara, more importantly improving student's quality. Science literacy dimensions that would be analyzed was science as context, science as knowledge, science as competence and science as attitudes.

\section{METHOD}

\subsection{Location, Population and Sample}

This research was conducted in North Labuhanbatu Utara Regency, North Sumatera from August 2019 to September 2019. The population was all $10^{\text {th }}$ grade high school students in North Labuhanbatu Utara (1829 students) from 8 schools in rural and urban regions of North Labuhanbatu Utara. The sample was 193 students from 3 schools in urban regions and 3 schools from rural regions. The sample was taken by purposive sampling method.

\subsection{Research Type and Design}

This was a descriptive research (Sukardi, 2003) which held to make a systematic, factual and accurate descriptions of $10^{\text {th }}$ grade student's science literacy skills in North Labuhanbatu Utara in dimensions of context, competence, knowledge and attitudes and region relation to science literacy.

\subsection{Instruments and Data Analysis Technique}

Data of student's science literacy skills was taken by using science literacy test which covers dimensions of context, competence, knowledge. Student' attitudes data was collected by using questionnaire. Data obtained was then analyzed by using Microsoft Excel to count the scores. As prerequisite test, normality test and homogeneity test were performed. Mann Whitney test then performed to find out whether there was significant difference between $10^{\text {th }}$ grade student's science literacy in rural and urban regions of North Labuhanbatu Utara. All data was analyzed by using SPSS 21 program.

\section{RESULTS AND DisCUSSION}

\subsection{Results}

Student's science literacy skills in context dimension, competence dimension, knowledge dimension and attitudes dimension displayed in table 2 below.

Table2: $10^{\text {th }}$ grade high school student's science literacy skills in North Labuhanbatu Utara Regency

\begin{tabular}{|l|l|l|l|l|}
\hline \multicolumn{1}{|c|}{ No } & \multicolumn{1}{|c|}{ Dimension } & \multicolumn{1}{|c|}{ N } & \multicolumn{1}{c|}{ Science literacy skills scores } & \multicolumn{1}{c|}{ Note } \\
\hline 1. & Context & 193 & 33.71 & Low \\
\hline 2. & Competence & 193 & 36.93 & Low \\
\hline 3. & Knowledge & 193 & 30.50 & Low \\
\hline 4. & Attitudes & 193 & 44.27 & Low \\
\hline & Average score & $\mathbf{1 9 3}$ & $\mathbf{3 6 . 3 5}$ & Low \\
\hline
\end{tabular}

According to table 2, the average score for tenth grade high school student's science literacy skills in North Labuhanbatu Utara regency 36.35 in low level.

The average score for context dimension was 33.71, competence dimension was 36.93 , knowledge dimension was 30.50, and attitudes dimension was 44.27. Results of all dimensions observed were in low level. Results of student's science literacy skills based on their school locations displayed in table 3 below.

Table3: $10^{\text {th }}$ grade high school student's science literacy skills in North Labuhanbatu Utara Regency based on school locations

\begin{tabular}{|l|c|c|c|c|c|}
\hline No & Dimension & \multicolumn{4}{|c|}{ School locations } \\
\cline { 3 - 5 } & & $\mathbf{n}$ & Urban region & $\mathbf{n}$ & Rural region \\
\hline
\end{tabular}




\begin{tabular}{|l|l|l|l|l|l|}
\hline 1. & Context & 97 & 34.91 & 96 & 38.96 \\
\hline 2. & Competence & 97 & 31.48 & 96 & 35.97 \\
\hline 3. & Knowledge & 97 & 28.04 & 96 & 32.99 \\
\hline 4. & Attitudes & 97 & 43.64 & 96 & 44.90 \\
\hline & Average score & $\mathbf{9 7}$ & $\mathbf{3 4 . 5 2}$ & $\mathbf{9 6}$ & $\mathbf{3 8 . 0 8}$ \\
\hline
\end{tabular}

According to table 3, the average score of student's science literacy skills inurban regions was 34.52 and in rural regions was 38,08. Result of Mann-Whitney test analysis for student's science literacy based on locations displayed in table 4 .

Table4: Test analysis for student's science literacy based on locations

\begin{tabular}{|l|l|l|l|l|l|l|l|}
\hline No & Dimension & \multicolumn{6}{|l|}{ Mann Whithney test results } \\
\hline & & N & Urban (Rank) & n & Rural (Rank) & P \\
\hline 1. & Context & 97 & 87.47 & 96 & 106.63 & 0.016 \\
\hline 2. & Competence & 97 & 84.12 & 96 & 110.01 & 0.001 \\
\hline 3. & Knowledge & 97 & 86.52 & 96 & 107.59 & 0.008 \\
\hline 4. & Attitudes & 97 & 84.51 & 96 & 109.62 & 0.002 \\
\hline
\end{tabular}

According to table 4, tenth grade high school student's science literacy skills based on the school locations in North Labuhanbatu Utara in competence dimension was highly significantly different and in context was significant, knowledge and attitudes dimensions was highly significant.

\subsection{Discussion}

\subsubsection{Tenth grade high school student's science literacy skills in North LabuhanBatu}

Average scores for student's science literacy was 36.35 , with the average score for context dimension was 33.71, competence dimension was 36.93, knowledge dimension was 30.50 , and attitudes dimension was 44.27. The overall results indicated that student's science literacy in North Labuhanbatu Utara Regency was low. In general, it indicates that most students do not yet have the characteristics of an individual who is literate in science. They don't be able to relate the concepts in their daily lives. This situation might occur because students haven't familiarized themselves with the type of questions in PISA or insufficient school facilities that support science literacy.

Fitriani (2018) in her research concluded that the low science literacy of eleventh grade students of students in Aceh Tamiang Regency was caused by students not yet familiar with the characteristics of the questions used in the study involving certain issues as context. In addition, Dinar (2013) said that Indonesian students have not been trained to solve problems with characteristics of PISA questions, which are always involve context in each of their items, both personal, social and local contexts.

Improving quality of learning assessment can be done steps to familiarized students with questions that promotes critical thinking. Beside context, the test used in assessing student's science literacy should have explanation for question introduction, which require ability to read and understanding the questions. The lack of interest in reading and reading skillsalso makes student science literacy became low. Hadi and Mulyatiningsih (2009) proves student's science literacy significantly influenced by reading skills, mathematics, learning culture, learning resources, educational facilities and the availability of internet connections. Therefore if reading skills increase, then mathematical and science skills will increase.

\section{- Student's Science Literacy in Context Dimension}

The average scores of North Labuhanbatu Utara student's science literacy skills in context dimension was 33.71, indicates poor ability in mastering the context of science literacy. The results also showed most students do best in local context of context dimension. Teacher's tendency to provide material without linking it to real life situations causes students to have difficulty in associating the knowledge they have with real life situations. This can be seen from non-practical answers of students, they have not been able to apply the concept to solve the scientific problems found in questions. Increasing exploring nature activities is one of the solutions for this problem. The surrounding environment can be explored by students as source of learning to improve their science literacy skills in local, personal, 
and global contexts. The exploration can be done in or outside school hours. The teacher can provide an activity guide, then learners explore with groups or individually.

\section{- Student's Science Literacy in Competence Dimension}

Analysis on student's science literacy obtained the score for competence dimension was 36.93 (low level), wherethe most competency mastered by students was explaining scientific phenomena.This describes that science literacy skills of students appears in the ability to recognize and remember simple concepts of science; explaining and describing a model; propose and predict hypotheses; and applying scientific knowledge in everyday life.At the point of explaining the phenomenon scientifically, students not only need ability to recall and used their existing knowledge (content knowledge), but also need knowledge about standard procedure used in scientific discovery (procedural knowledge), knowledge of ideas and explanations of characteristics that are essential to knowledge formation process and in proving the truth of knowledge produced by science (OECD, 2016).

\section{- Student's Science Literacy in Knowledge Dimension}

The average scores of North Labuhanbatu Utara student's science literacy skills in knowledge dimension was 30.50 ,indicates poor ability in mastering science literacy in knowledge dimension. The bestaspect of the knowledge dimension is in aspect of the content knowledge. This result was supported by another result that stated student's knowledge aspect was higher compared to the use of science knowledge in text or article analysis and problem solving aspect (Pantiwati \& Husamah, 2014).

Content knowledge is a knowledge that relevant to real life situations. In this indicator, Physic teacher candidates already have good content knowledge. This is happened because teacher able to solve problems related to real life situation. This result in line with the opinions that explained someone has good content knowledge if they able to reveal investigations related to cases that scientifically in accordance with real life (Elsy, 2018).

\section{- Student's Science Literacy in Attitudes Dimension}

Data analysis showed that student's science literacy in North Labuhanbatu Utara in attitudes dimension was 44.27 or in low level category.

People response differently from one another. Gerungan (in Azzahra, 2014) explained that this different attitudes occur because human inner attitudes influenced by many factors, such as desires, knowledge, experiences, habits, and social interactions that occur in groups or outside the group. All these factors can influence attitudes of generate a new attitudes.

Further, student's positive attitudes towards science can be influenced by student's confidence in solving the problems. Research by Dewi (2014), found that students in low category have high confidence. They tend to be sure in answering the questions even if only based on intuition.

\subsubsection{Student's Science Literacy based on School Locations}

Based on school locations, science literacy of tenth grade students in North Labuhanbatu Utara was in low category, where in urban regions scored 34.52 and in rural regions scored 38.08. the low achievement in science literacy might cause by insufficient learning facilities. In line with Fatkhuri, (2013), geographically rural regionsare indeed located at a considerable distance from urban areas and it can be confirmed that the rural population has very limited access to various sources such as education. This limited access will effect on facilities availability to meet teaching and learning needs

Result of data analysis showed that science literacy skills of students in rural regions was higher compared to urban regions, it might be because students in rural regions have better ways of thinking, more enthusiastic about the future, students in the village are also highly motivated in solving problems, have higher curiosity,respect other people more and have a curiosity about new things.Hamdu and Agustina (2011) proved that there are significant influence of motivation to learning outcome.

Fitriani (2018) proposed that difference science literacy between students in urban and rural regions 
also influence by different kinship levels between the two regions. Students who live in rural regions tend to live in a healthier family environment, therefore theirs social attitudes to others were good and they tend to respect the activities carried out by others.

\section{CONClusion}

Based on research results and data analysis, it can be concluded:

Tenth grade student's science literacy in North Labuhanbatu Utara was $36.35 \%$, or in low level. Student's science literacy in context dimension was 33.71 or in a low level. Student's science literacy in competence dimension was 36.93 , or in a low level. Student's science literacy in knowledge dimension was 30.50 ,or in a low level. Student's science literacy in attitudes dimension was 44.27,or in a low level. There was significant difference in science literacy between students in urban regions (34.52) and students in rural regions (38.08), student's science literacy in rural regions were better compared to students in urban regions.

\section{REFERENCES}

[1] Anggraini, G. 2014. Analisis Kemampuan Literasi Sains Siswa SMA Kelas X di Kota Solok. Journal of Education Informatic Technology and Science, 1 (1) : 114-124

[2] Azzahra, S.F. 2014. Pengingkatan Keterampilan Berpikir Kritis dan Sikap Ilmiah Siswa pada Materi Termokimia Melalui Pembelajaran Group dan Individual Problem Solving, Universitas Pendidikan Indonesia, Bandung.

[3] Laugksch, R. 2000. Scientific literacy: a conceptual overview', Science Education

[4] Ogunkola, B. 2013. Scientific Literacy: Conceptual Overview, Importance and Strategies for Improvement. Journal of Educational and Social Research, 3(1), 265-274.

[5] OECD. 2013. Survey International Program for International Student Assessment (PISA)

[6] OECD. 2016. Programme for nternational Student Assesment (PISA) Results From PISA 2015.

[7] Siagian, P., Silitonga, M., \& Djulia, E. Scientific Literacy Skills of Seventh Grade Junior High School (SMP Negeri) Students in North Labuhanbatu Regency. (2017). International Journal of Humanities, Social Sciences and Education, 4(11).

[8] Fitriani, et all. 2018. Analisis kemampuan literasi sains biologi siswa Sma kelas XI Ipa Se-Kabupaten Aceh Tamiang. International Journal of Research \& Review.5(3):63.

\section{AUTHORS'BIOGRAPHY}

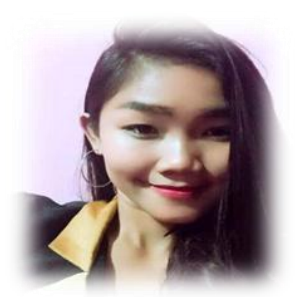

Yenni Wati Sinaga,S.Pd, is a Biology Education postgraduate student at Postgraduate Programe of Universitas Negeri Medan (Medan State University), Medan, North Sumatera, Post code 20221, Indonesia. She obtained her Bachelor Degree in Biology Education from Universitas Negeri Medan (Medan State University), and her Master Degree in Biology Education from Universitas Negeri Medan (State University of Medan), Medan, Indonesia.

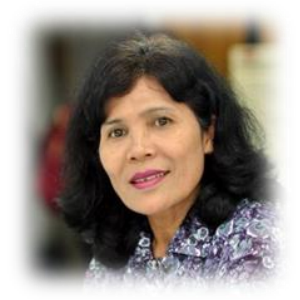

Dr. Melva Silitonga,M.S, is a lecturer at Graduate and Postgraduate Programe of Universitas Negeri Medan (Medan State University), Medan, North Sumatera, Post code 20221, Indonesia. She obtained her Sarjana Degree (S1) in Biology Education from IKIP Medan, herMagister degree (S2) of science in biology from Bogor Agriculture Institute (IPB Bogor) and her Doctor Degree (S3) in Biology Program from Universitas Sumatera Utara (North Sumatera University) Medan.

Citation: Melva Silitonga, et.al. "Comparison of scientific literacy skills based on gender in north Labuhanbatu district". International Journal of Humanities Social Sciences and Education (IJHSSE), vol. 6, no.12, 2019, pp. 50-54. doi: http://dx. doi.org/10.20431/2349-0381.0612003.

Copyright: (C) 2019 Authors. This is an open-access article distributed under the terms of the Creative Commons Attribution License, which permits unrestricted use, distribution, and reproduction in any medium, provided the original author and source are credited. 